\title{
The Validation and Development of Analytical Technique for the Fast and Economical Evaluation of Amoxicillin in Solid Dosage form Through UV/Visible Spectroscopy
}

\author{
Muhammad lqbal',3, Syed Saeed ul Hassan², Muhammad Abbas ${ }^{4, *}$, Hammad Ahmad ${ }^{2,5}$ \\ ${ }^{1}$ Department of Chemistry, University of Gujrat, Hafiz Hayat Campus, Gujrat 50700, Pakistan. \\ 2 Imran Idrees College of Pharmacy, Sialkot, Pakistan. \\ ${ }^{3}$ Munawar Pharm Lahore, Pakistan. \\ ${ }^{4}$ Ismam College of Pharmacy, Pasrur Road Sialkot-51480, Pakistan. \\ ${ }^{5}$ Department of Pharmacology, Sialkot Medical College, Pakistan.
}

\begin{abstract}
Authors' Contributions
1 Conception \& Study design, Data Collection \& Processing, Data Analysis and/or Interpretation, Drafting of Manuscript.

2 Conception \& Study design, Data Collection

\& Processing, Data Analysis and/or Interpretation, Critical Review.

3 Data Collection \& Processing, Data Analysis and/or Interpretation, Drafting of Manuscript Critical Review.

4 Data Analysis and/or Interpretation, Critical Review.

\section{Article info.}

Received: December 22, 2020

Accepted: April 15, 2021

Funding Source: Nil

Conflict of Interest: Nil

Cite this article: Iqbal M, Hassan SSU, Abbas $M$, Ahmad $H$. The Validation and Development of Analytical Technique for the Fast and Economical Evaluation of Amoxicillin in Solid Dosage form Through UVNisible Spectroscopy. RADS J Pharm Pharm Sci. 2021; 9(1):7-17.
\end{abstract}

*Address of Correspondence Author: abbaspk1@gmail.com

\begin{abstract}
A B S T R A C T
Objective: The key objective of the study is to explore the sensitive, rapid, simple, accurate and economic UV/Vis spectrophotometric method to determine the amount of Amoxicillin trihydrate (AMTR) in bulk pharmaceuticals and in various formulations including dry powder (syrup), tablets and capsules by employing Copper sulphate buffer solution.
\end{abstract}

Methodology: The current spectroscopic analysis performed with $12.5 \mu \mathrm{g} / \mathrm{ml}$ concentration of AMTR at $320 \mathrm{~nm}$ follows the Beer's Lambert Law. The linearity range $(10-15 \mu \mathrm{g} / \mathrm{ml})$ and regression data presented a significant correlation coefficient $\left(r^{2}=0.999\right)$. The appropriate level of accuracy, precision, linearity, and mean percentage recovery of AMTR were found adequate relating to the $\%$ age error and standard deviations.

Results: Amoxicillin trihydrate and its known strengths were scanned and analyzed by our validated method such as; $10.0 \mu \mathrm{g} / \mathrm{ml}$ Amoxicillin $(80 \%)$, $11.25 \mu \mathrm{g} / \mathrm{ml}$ Amoxicillin (90\%), $12.5 \mu \mathrm{g} / \mathrm{ml}$ Amoxicillin (100\%), $13.75 \mu \mathrm{g} / \mathrm{ml}$ Amoxicillin (110\%) and $15.0 \mu \mathrm{g} / \mathrm{ml}$ Amoxicillin (120\%).

Conclusions: As the recommended protocol of amoxicillin determination (spectrophotometry) is accurate, precise and statistically evaluated, therefore it could readily be employed for qualitative purposes of either for the raw material and pharmaceutical preparations.

Keywords: UV/Vis Spectroscopy, validation, amoxicillin trihydrate, Pharmaceutical, formulations.

\section{INTRODUCTION}

Amoxicillin is associated to $\beta$ lactam antibiotics and effectively respond to Gram +ve and Gram -ve strains of bacteria. The infectious diseases in animals, humans and plants are effectively control with Amoxicillin [1]. It is hydrolyzed by the staphylococcal penicillaminase [2]. Amoxicillin is found in three hydrated forms such as; monohydrate, dehydrate and trihydrate, while, the trihydrated form is the supreme stable [3]. Chemical name of Amoxicillin trihydrate (AMTR) is $(2 S, 5 R, 6 R)-6-[[(2 R)-2$ Amino- 2 -(4-hydroxyphenyl)-acetyl]amino] -3, 3dimethyl -7 -oxo- 4 - thia- 1- azabicyclo [3.2.0] heptane- 2-carboxylic acid trihydrate [4]. Its molecular weight and molecular formula are 419.4 and 
The Validation and Development of Analytical Technique for the Fast and Economical Evaluation of Amoxicillin in Solid Dosage form Through UV/Visible Spectroscopy

$\mathrm{C}_{16} \mathrm{H}_{19} \mathrm{~N}_{3} \mathrm{O}_{5} \mathrm{~S} .3 \mathrm{H}_{2} \mathrm{O}$ respectively as well as structuralformula [5] is given in Figure 1.

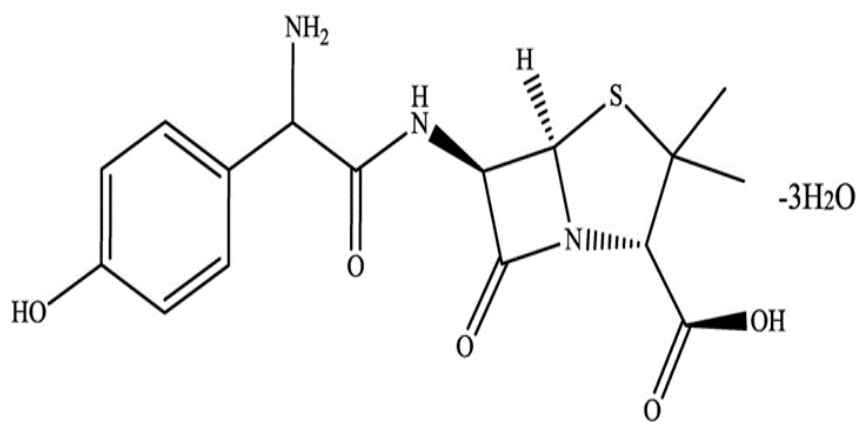

Figure 1. Structure of Amoxicillin-trihydrate.

AMTR is a white crystalline-powder. It is slightlysoluble in water and ethanol (96\%), practicallyinsoluble in oils of fatty acid. In dilute acids and dilute alkali hydroxides it dissolves in between $15^{\circ} \mathrm{C}-25^{\circ} \mathrm{C}$. It melts at about $183^{\circ} \mathrm{C}$ with decomposition characteristics. Drug is officially listed in British Pharmacopoeia, United States Pharmacopoeia and Martindale [6]. Because of therapeutic significance of Amoxicillin, biological and quality control labs required rapid, sensitive and reliable method to monitor it clinically [1]. Therefore, numerous analytical methods have been reported for the estimation of Amoxicillin in bulk and pharmaceutical dosage forms like spectrophotometric [6,7], HPLC [9,10], derivativespectrometric and titrimetric techniques $[3,11]$. The current study is focused on the validation of simple, precise and economical UV/Vis spectrophotometer method to evaluate the Amoxicillin trihydrate in pure and formulations.

\section{EXPERIMENTAL}

\section{Preparation of Copper Sulphate buffer solution}

Di-potassium hydrogen phosphate was weighed $(15.22 \mathrm{~g})$ and dissolved in $900 \mathrm{ml}$ distilled water. Citric acid monohydrate (9.744g) and copper sulphate pentahydrate $(0.117 \mathrm{~g})$ were added to the solution and sonicated. The final $1000 \mathrm{~mL}$ volume was made with distilled-water. [12].

\section{Reagents and Solvents}

The standard (reference) Amoxicillin trihydrate analytical grade $(99.88 \%)$ and the dry powder (oral suspension) containing excipients were acquired from Munawar Pharma Lahore and stored at room temperature. All other chemicals were of analytical grades and water was freshly dual distilled.

\section{Instrumentation and Conditions}

All analytical works were performed with double-beam UV/Vis spectrophotometer (Shimadzu UV-1700) fitted out with dual lamp as energy source and UV-Visible detector. Analytical balance (Sartorius model TE214S) was used for weighing solid chemicals.

\section{Development of UV-Vis Spectrophotometer Method}

\section{Standard Solution preparation for Linearity}

Solution of Amoxicillin trihydrate equivalent to 62.5 $\mathrm{mg}$ was prepared by dissolving $72 \mathrm{mg}$ of standard Amoxicillin in $180 \mathrm{ml}$ distilled water and diluted to 200 $\mathrm{ml}$ with water. Filtered after proper shaking, the $1^{\text {st }}$ portion of filtrate was discarded and remaining filtrate was stored as stock solution. Then $02 \mathrm{ml}$ of stock solution was diluted to $50 \mathrm{ml}$ with Copper sulphate buffer. We heated $\left(60-70^{\circ} \mathrm{C}\right)$ mixture in water-bath for 30 minutes and cooled in ice-bath to $25^{\circ} \mathrm{C}$. The strength of resulting solution was $12.5 \mu \mathrm{g} / \mathrm{ml}$, it scanned at $250-350 \mathrm{~nm}$ with UV/Visible spectrophotometer using copper sulphate buffer as a blank. The $\Lambda_{\max }$ we perceived was $320 \mathrm{~nm}$ [13].

We perceived linearity and precision of Amoxicillin in ranges of $10-15 \mu \mathrm{g} / \mathrm{mL}$ after preparation of 05 dilutions $(80 \%, 90 \%, 100 \%, 110 \%$ and $120 \%)$ from the stock solution of reference standard [14].

\section{Preparation of Standard/Sample Solution}

The standard solution of sample Amoxcillin powder was prepared by dissolving $72 \mathrm{mg}$ of powder equivalent to $62.5 \mathrm{mg}$ of ${ }^{\circ} \mathrm{Amoxicillin}{ }^{\circ}$ in $200 \mathrm{ml}$ distilled water. After filtration, we discarded first portion of filtrate and remaining amount was collected as stock solution. $02 \mathrm{ml}$ of stock-solution was mixed with $48 \mathrm{ml}$ copper sulphate buffer. Then mixture was heated in water-bath for $30 \mathrm{~min}$ and cooled to $25^{\circ} \mathrm{C}$ with ice-bath. The strength of resulting solution was $12.5 \mu \mathrm{g} / \mathrm{mL}$ [15].

\section{Preparation of Sample solution of some Commercial Brands \\ CLOCIL, AMOXICAP and LOMOXY Dry powder for Oral suspension $125 \mathrm{mg} / 5 \mathrm{ml}$}

The sample solution of dry powder of samples we made by liquefying appropriate amount of drugs equivalent to $62.5 \mathrm{mg}$ of Amoxicillin in $200 \mathrm{ml}$ distilled 
The Validation and Development of Analytical Technique for the Fast and Economical Evaluation of Amoxicillin in Solid Dosage form Through UV/Visible Spectroscopy

water. Then filtered and required strength of commercially available drugs was prepared with buffer solution in similar fashion as done with standards i.e., $12.5 \mu \mathrm{g} / \mathrm{mL}$ [15]. The optimized situations of the proposed protocol and regression calibration were accessible in Table $\mathbf{1}$ and Table 2.
UV-Vis. Spectrophotometer

Drug Solubility

Solubility of the drug was observed in double distilled water [16].

Table 1. Optimized Conditions for the Proposed Method.

\begin{tabular}{|c|c|c|}
\hline $\mathbf{S} / \mathbf{N}$ & Parameters & Optimized condition \\
\hline 1 & Quartz Cell & Quartz Cell $1 \mathrm{~cm}$ \\
\hline 2 & Solvent (s) & Double distilled water; Copper sulphate buffer solution \\
\hline 3 & Concentration used & $12.5 \mu \mathrm{g} / \mathrm{ml}(0.00125 \%)$ \\
\hline 4 & Cell volume & $1 \mathrm{ml}$ \\
\hline 5 & Detection wavelength $(\boldsymbol{\Lambda})$ & $320 \mathrm{~nm} \mathrm{UV/Vis} \mathrm{Spectrophotometer}$ \\
\hline 6 & Temperature & ambient \\
\hline
\end{tabular}

Table 2. Regression Study for the Calibration.

\begin{tabular}{|c|c|c|}
\hline Sr. No. & Considerations & Optimized condition \\
\hline 1 & Linearity-range $(\mu \mathrm{g} / \mathrm{mL})$ & $10-15 \mu \mathrm{g} / \mathrm{ml}$ \\
\hline 2 & Correlation coefficient $\left(\mathrm{r}^{2}\right)$ & 0.999 \\
\hline
\end{tabular}

\section{RESULTS}

\section{Instrument Precision}

Table 3. Instrument Precision

\begin{tabular}{|c|c|c|}
\hline Sr. No. & $\begin{array}{c}\text { Absorption of Standards } \\
\text { (Amoxicillin trihydrate) }\end{array}$ & Statistical Calculations \\
\hline 1. & 0.364 & Mean $=\underline{0.364+0.366+0.363+0.364+0.365}$ \\
\hline 2. & 0.366 & 5 \\
$=0.364$ \\
\hline 3. & 0.363 & Std Deviation $=0.19$ \\
RSD $= \pm 0.198 \%$
\end{tabular}

The precision was determined using Amoxicillin standards which established mean value 0.364 , standard deviation 0.19 and RDS value $0.198 \%$ as given in Table 3 . The scan of standard Amoxicillin and its target set value is given in Figures 2A and 2B.

\section{Validation protocol}

Establishing documented evidence that a system does what it purports to do. Analytical validation essentially means the examination of six basic attributes such as; Linearity and range, Precision, Accuracy, Robustness, Sensitivity and Specificity. 
The Validation and Development of Analytical Technique for the Fast and Economical Evaluation of Amoxicillin in Solid Dosage form Through UVNVisible Spectroscopy

\section{Linearity}

Results of a trial proportional to the concentrations of analytes (sample) is called linearity. The linearrelationship amid the concentration and absorbance at wavelength $320 \mathrm{~nm}$ was confirmed by plotting the graph between these two parameters in the range of $80,90,100,110$ and $120 \%$ of the target value (12.5 $\mu \mathrm{g} / \mathrm{ml}$ Amoxicillin) [17].

The calibration graph is shown below, indicated the linear association observed between concentration versus absorbance of solution measured at $\Lambda 320 \mathrm{~nm}$.

The correlation coefficient of calibration data was calculated to 0.999 .

This indicates that the test procedure obeys the Beer's law.

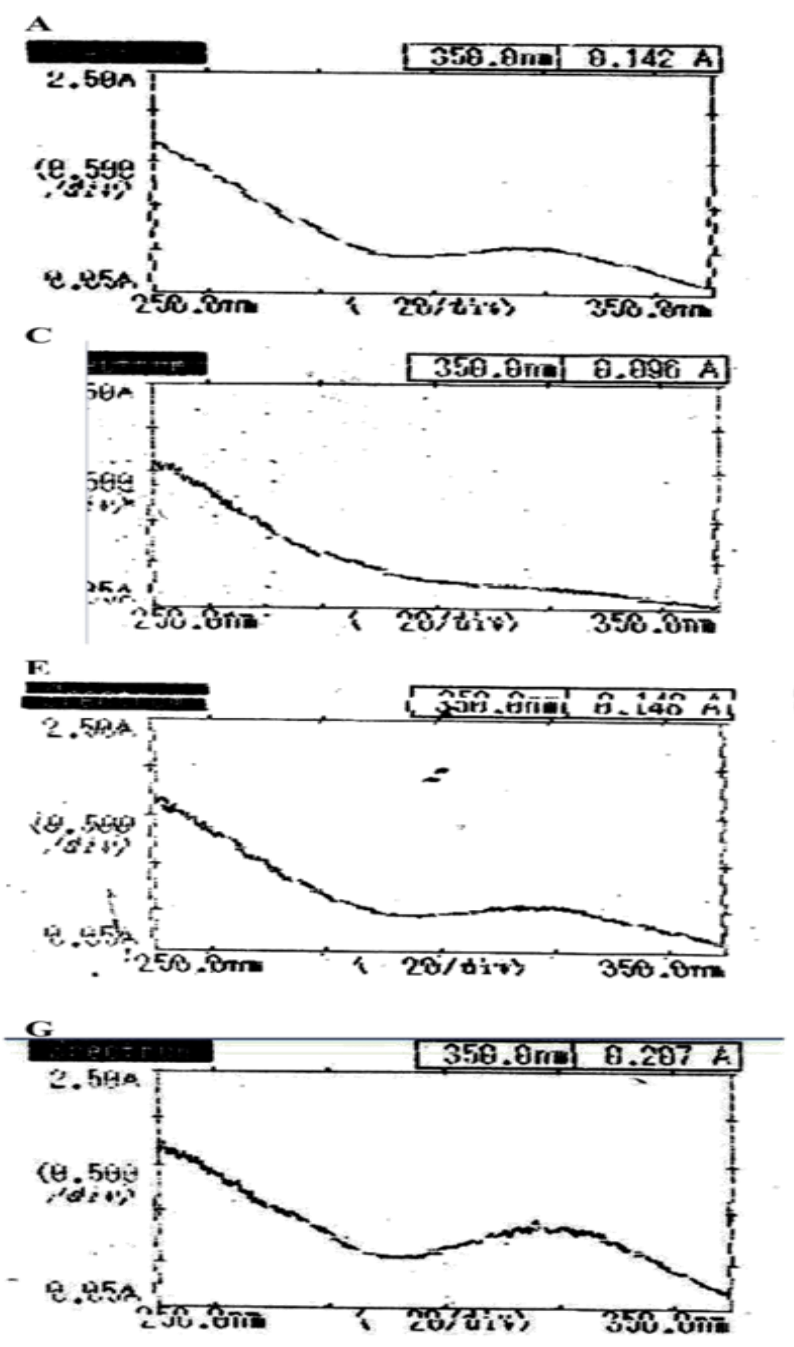

\section{Standard Preparation for Linearity}

The stock solution $(12.5 \mu \mathrm{g} / \mathrm{ml})$ of standard Amoxicillin was prepared similar to prepared earlier. For the preparation of series of solution, pipetted out $1.6 \mathrm{ml}, 1.8 \mathrm{ml}, 2.0 \mathrm{ml}, 2.2 \mathrm{ml}$ and $2.4 \mathrm{ml}$ respectively from organized stock solution in secluded $50 \mathrm{ml}$ measuring flasks, then added Copper sulphate (buffer) solution to each flask and made up-to the volume $(50 \mathrm{ml})$. The resulting dilutions related to standard stock were made as $80 \%, 90 \%, 100 \%$, $110 \%$ and $120 \%$ of drug respectively [18]. The scan of standards Amoxicillin solutions and their \% age of target values were presented in Figures 2B, 2C, 2D, $2 \mathrm{G}$ and $2 \mathrm{~F}$.
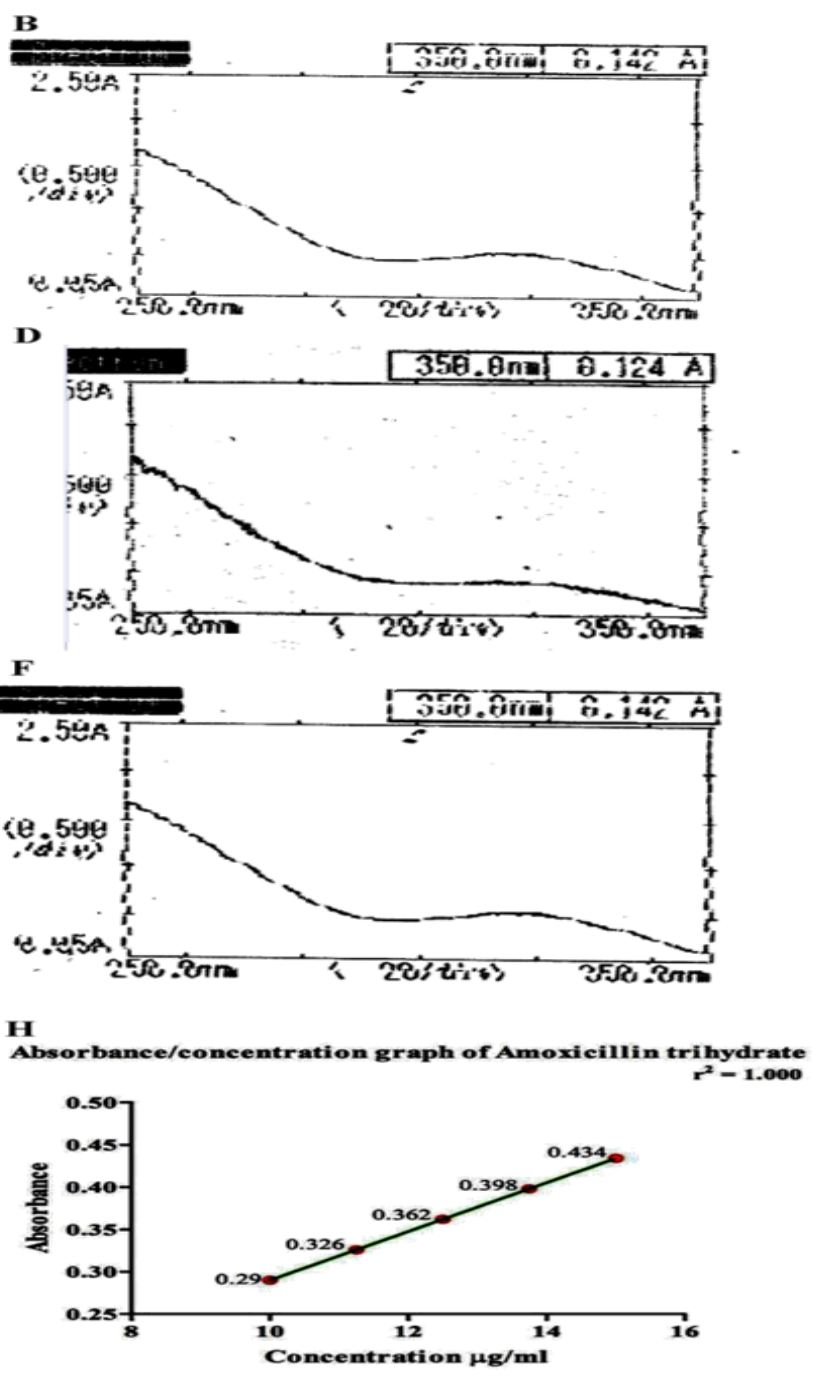

Figure 2. A: Scan of standard $(12.5 \mu \mathrm{g} / \mathrm{ml}$ Amoxicillin solution), B: Scan of standard $(12.5 \mu \mathrm{g} / \mathrm{ml}$ Amoxicillin solution) target set value, C: Scan of standard $(10.0 \mu \mathrm{g} / \mathrm{ml}$ Amoxicillin) $80 \%$ of target set value, D: Scan of standard (11.25 $\mu \mathrm{g} / \mathrm{ml}$ Amoxicillin) $90 \%$ of target set value, E: Scan of standard (12.5 $\mu \mathrm{g} / \mathrm{ml}$ Amoxicillin) $100 \%$ of target set value, F: Scan of standard $(13.75 \mu \mathrm{g} / \mathrm{ml}$ Amoxicillin) $110 \%$ of target set value, G: Scan of standard 
The Validation and Development of Analytical Technique for the Fast and Economical Evaluation of Amoxicillin in Solid Dosage form Through UVNVisible Spectroscopy

(15.0 $\mathrm{\mu g} / \mathrm{ml} \mathrm{Amoxicillin)} 120 \%$ of target set value, $\mathbf{H}$ : Linear Regression Line of Amoxicillin trihydrate (Concentration vs absorbance).

\section{Acceptance Criteria}

Correlation Coefficient $\left(r^{2}\right)=-1$ to +1

Table 4. Amoxicillin Trihydrate Concentration and Absorbance Relationship in Linear Regression.

\begin{tabular}{|c|c|c|c|c|}
\hline Sr.\# & $\begin{array}{c}\text { Volume of the } \\
\text { Solution (taken) }\end{array}$ & $\begin{array}{c}\text { \%age Conc. of } \\
\text { Target Value }\end{array}$ & $\begin{array}{c}\text { Concentration } \\
(\mu \mathrm{g} / \mathrm{ml})\end{array}$ & $\begin{array}{c}\text { Absorbance of the test } \\
\text { solution. }\end{array}$ \\
\hline 1 & $1.6 \mathrm{ml}$ & $80 \%$ & $10.0 \mu \mathrm{g} / \mathrm{ml}$ & 0.290 \\
\hline 2 & $1.8 \mathrm{ml}$ & $90 \%$ & $11.25 \mu \mathrm{g} / \mathrm{ml}$ & 0.326 \\
\hline 3 & $2.0 \mathrm{ml}$ & $100 \%$ & $12.5 \mu \mathrm{g} / \mathrm{ml}$ & 0.362 \\
\hline 4 & $2.2 \mathrm{ml}$ & $110 \%$ & $13.75 \mu \mathrm{g} / \mathrm{ml}$ & 0.398 \\
\hline 5 & $2.4 \mathrm{ml}$ & $120 \%$ & $15.0 \mu \mathrm{g} / \mathrm{ml}$ & 0.434 \\
\hline
\end{tabular}

It is cleared from the calibration chart that linear relationship existed and followed the Beer's Law between absorbance and the concentration of analyte presented in Table $\mathbf{4}$ and illustrated in Figure $\mathbf{2 H}$.
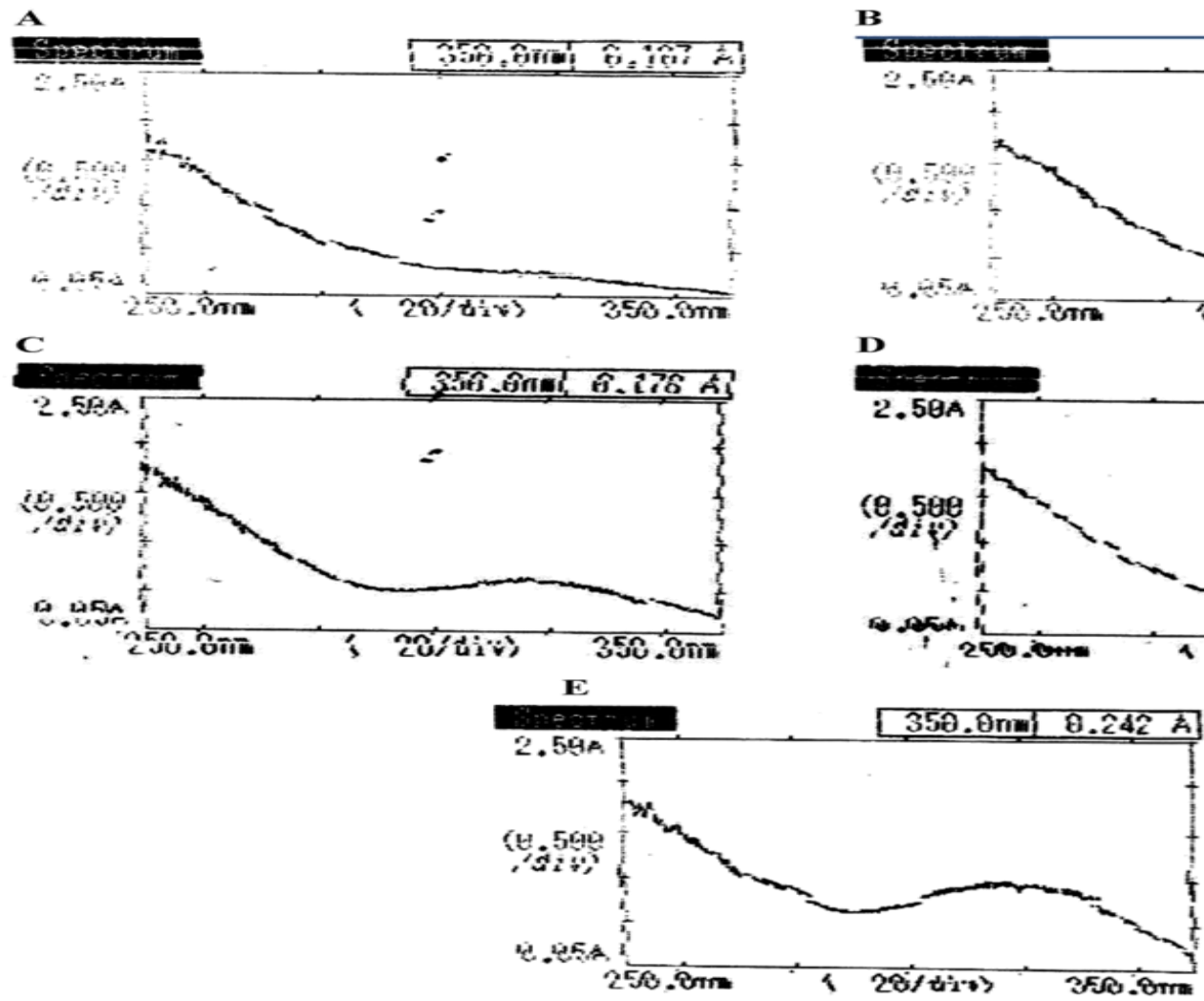

Figure 3. A: Scan of Test Sample $(10.0 \mu \mathrm{g} / \mathrm{ml}$ Amoxicillin solution), B: Scan of Test Sample $(11.25 \mu \mathrm{g} / \mathrm{ml}$ Amoxicillin solution), C: Scan of Test Sample (12.5 $\mu \mathrm{g} / \mathrm{ml}$ Amoxicillin solution), D: Scan of Test Sample (13.75 $\mu \mathrm{g} / \mathrm{ml}$ Amoxicillin solution), E: Scan of Test Sample (15.0 $\mu \mathrm{g} / \mathrm{ml}$ Amoxicillin solution). 
The Validation and Development of Analytical Technique for the Fast and Economical Evaluation of Amoxicillin in Solid Dosage form Through UVNVisible Spectroscopy

\section{Acceptance Criteria}

The interval between upper and lower concentration of analyte in analytical procedure has appropriate level of accuracy, precision, and linearity [19]. The \% age relative $\mathrm{SD}$ of triplicates obtained at each level (80\%, $100 \%, 120 \%)$. NMT $2.0 \% \pm$ RSD.

\section{Procedure}

The range $80 \%$ to $120 \%$ is when the accuracy, precision and linearity $80 \%$ and $120 \%$ are established, \% age RSD of triplicates at each level (80\%, $100 \%, 120 \%)$ is $<2.0 \%$ and average of triplicate values obtained at each level $(80 \%, 100 \%$, $120 \%)$.

Hence, the range from $80 \%$ to $120 \%$ is established.

\section{Precision}

Precision is the degree of how close the individual test results to the replicates of same analyte sample under identical conditions [20].

Precision is commonly expressed as Relative Standard-Deviation (Coefficient of variation). Precision is performed through;

\section{a - Repeatability}

b- Reproducibility.

Table 5. Results of Repeatability.

\begin{tabular}{|c|c|c|c|c|c|}
\hline \multirow{2}{*}{\multicolumn{2}{|c|}{ Samples }} & \multicolumn{4}{|c|}{ Repeatability Results } \\
\hline & & \multirow{2}{*}{$\begin{array}{c}\text { Concentration of analyte } \\
(\mu \mathrm{g} / \mathrm{ml})\end{array}$} & \multirow{2}{*}{$\begin{array}{c}\text { Absorbance } \\
0.364\end{array}$} & \multirow{2}{*}{$\begin{array}{c}\text { \%age Results } \\
100.27 \%\end{array}$} & \multirow{2}{*}{$\begin{array}{c}\begin{array}{c}\text { Variation from } \\
\text { Theoretical Results }\end{array} \\
0.27 \% \\
\end{array}$} \\
\hline \multirow{3}{*}{ I } & 1 & & & & \\
\hline & 2 & 12.5 & 0.362 & $99.72 \%$ & $0.28 \%$ \\
\hline & 3 & 12.5 & 0.365 & $100.55 \%$ & $0.55 \%$ \\
\hline \multirow{3}{*}{ II } & 4 & 12.5 & 0.361 & $99.44 \%$ & $0.66 \%$ \\
\hline & 5 & 12.5 & 0.366 & $100.82 \%$ & $0.82 \%$ \\
\hline & 6 & 12.5 & 0.364 & $100.27 \%$ & $0.27 \%$ \\
\hline
\end{tabular}

Average of 6 Results: $\quad 100.17 \%$

Standard Deviation: $\quad 0.469$

\%RSD:

$0.47 \%$

RSD of 6 Results is: $100.17 \pm 0.47 \%$ (Limit: NMT $2 \%$ ). The results in the tabulation form presented in Table 5.

\section{Reproducibility}

The utilization of analytical procedure by different analyst within the same laboratory is referred

\section{Sample Stock Solution $(\mathbf{1 2 . 5} \mu \mathrm{g} / \mathrm{ml})$}

Weighed accurately $1.0417 \mathrm{~g}$ of sample powder equivalent to $62.5 \mathrm{mg}$ of Amoxicillin in $200 \mathrm{ml}$ measuring-flask and dissolved in $180 \mathrm{~mL}$ of double distilled water then diluted to $200 \mathrm{ml}$ by means of same solvent and shaken well to mix. Filtered and discarded first portion of filtrate while remaining part was collected as stock solution. Diluted $2.0 \mathrm{ml}$ stocksolution up-to $50 \mathrm{ml}$ with Copper sulphate buffer. Heated in waterbath for half an hour $\left(70^{\circ} \mathrm{C}\right)$ and then cooled to room temperature.

\section{Repeatability}

Assay was performed on three separate samples in 02 replicates.

Concentration of Reference: $\quad 12.5 \mu \mathrm{g} / \mathrm{ml}$

Wavelength:

$320 \mathrm{~nm}$

Absorbance of the Reference: $\quad 0.363$ 
The Validation and Development of Analytical Technique for the Fast and Economical Evaluation of Amoxicillin in Solid Dosage form Through UV/Visible Spectroscopy

Table 6. The Response of Reproducibility.

\begin{tabular}{|c|c|c|c|c|}
\hline \multirow{2}{*}{ Samples } & \multicolumn{4}{|c|}{ Reproducibility Results } \\
\cline { 2 - 5 } & $\begin{array}{c}\text { Concentration of } \\
\text { analyte }(\boldsymbol{\mu g} / \mathbf{m l})\end{array}$ & Absorbance & \%age Results & $\begin{array}{c}\text { Variation from } \\
\text { Theoretical Results }\end{array}$ \\
\hline $\mathbf{1}$ & 12.5 & 0.362 & $99.72 \%$ & $0.28 \%$ \\
\hline $\mathbf{2}$ & 12.5 & 0.364 & $100.27 \%$ & $0.27 \%$ \\
\hline $\mathbf{3}$ & 12.5 & 0.365 & $100.55 \%$ & $0.55 \%$ \\
\hline
\end{tabular}

Average of 3 Results:

$100.18 \%$

Standard Deviation:

0.344

\% RSD:

$0.34 \%$

$\%$ RSD of 3 Results is: $100.18 \pm 0.34 \%$ ((Limit: NMT $2 \%$ )

\section{Accuracy}

It is measure of faithfulness of the analytical technique and its result value is close to the true value. The method is said to be accurate if on the average the method provides the true answer. Accuracy implies there is no inherent systematic error or bias - (bias is the deviation from true value). By using the reference standard the accuracy of a method can be measured and extent of bias that may exist can also be determined.

Actually accuracy of an analytical process is the closeness of test results attained specified protocol to the factual value. It is evaluated by the addition of known amounts of an analyte to the Placebo (sample) with different quantities $(3 \times 3$ replicates $)$ and is designed as the \%age recovery of known added amount of analyte to the Placebo.

\section{Placebo}

For this purpose three samples of about $200 \mathrm{~g}$ were organized in the laboratory, as per to the manufacturing route for the product, and quantities equivalent to $80 \%, 100 \%$ and $120 \%$ of the labeled amount of analyte were added to each placebo. Test solutions were prepared of each concentration (i.e. $80 \%, 100 \%$ and $120 \%$ ) assayed in duplicate and tested according to the test procedure of the product and results are to be tabulated in Table 7.

Concentrations of standards: $10 \mu \mathrm{g} / \mathrm{mL}, 12.5 \mu \mathrm{g} / \mathrm{mL}$, $15 \mu \mathrm{g} / \mathrm{mL}$

Wavelength: $\quad 320 \mathrm{~nm}$

Absorbance of the reference standard $80 \%=0.290$

Absorbance of the reference standard $100 \%=0.363$

Absorbance of the reference standard 120\%: 0.436

Table 7. The Variation of Theoretical and Claimed Placebo Concentration.

\begin{tabular}{|c|c|c|c|c|c|c|}
\hline \multirow{2}{*}{$\begin{array}{c}\text { Contents of Active added } \\
\text { in Placebo } \\
\text { (\% of Label claim) }\end{array}$} & \multicolumn{2}{|c|}{$80 \%$} & \multicolumn{2}{|c|}{$100 \%$} & \multicolumn{2}{|c|}{$120 \%$} \\
\hline & Sample1 & Sample2 & Sample-1 & Sample-2 & Sample1 & Sample2 \\
\hline Abs. of the test sample & 0.292 & 0.289 & 0.364 & 0.362 & 0.437 & 0.438 \\
\hline$\%$ age of label claim & $100.68 \%$ & $99.65 \%$ & $100.27 \%$ & $99.72 \%$ & $100.22 \%$ & $100.45 \%$ \\
\hline $\begin{array}{l}\text { Variation from theoretical } \\
\text { Results or difference }\end{array}$ & $0.68 \%$ & $0.35 \%$ & $0.27 \%$ & $0.28 \%$ & $0.22 \%$ & $0.45 \%$ \\
\hline Average or $\%$ age Recovery & \multicolumn{2}{|c|}{$100.16 \%$} & \multicolumn{2}{|c|}{$99.99 \%$} & \multicolumn{2}{|c|}{$100.33 \%$} \\
\hline $\begin{array}{c}\text { Standard Deviation of } \\
\text { Variation from Theoretical } \\
\text { Results }\end{array}$ & \multicolumn{2}{|c|}{ \pm 0.51} & \multicolumn{2}{|c|}{ \pm 0.27} & \multicolumn{2}{|c|}{ \pm 0.11} \\
\hline
\end{tabular}


The Validation and Development of Analytical Technique for the Fast and Economical Evaluation of Amoxicillin in Solid Dosage form Through UVNVisible Spectroscopy

\section{Robustness}

Robustness is a measurement of the capacity of an analytical procedure to remain unaffected by minor but deliberate deviations in parameters of protocol and offers an indication of its reliability in usual practice. The resulting changes are made deliberately in testing procedure. The test solutions are to be prepared according to the test procedure and kept the concentration of analyte same but the volume of solvent is changed and assayed according to the test procedure. The results are compiled with initial results and tabulated in Table 8.

Concentrations of standards: $\quad 12.5 \mu \mathrm{g} / \mathrm{ml}$

Wavelength $(\Lambda)$ : $\quad 320 \mathrm{~nm}$

Absorbance of the standard solution $=0.364$

Table 8. Determination of Label Claimed Versus Amount of Samples.

\begin{tabular}{|c|c|c|c|c|c|c|}
\hline \multirow{2}{*}{ Volume Variation } & \multicolumn{2}{|c|}{$\mathbf{5 0} \mathbf{~ m l}$} & \multicolumn{2}{c|}{$100 \mathrm{ml}$} & \multicolumn{2}{c|}{$200 \mathrm{ml}$} \\
\cline { 2 - 7 } & Sample-I & Sample -II & Sample-I & Sample-II & Sample-I & Sample-II \\
\hline $\begin{array}{c}\text { Sample } \\
\text { concentration } \\
\begin{array}{c}\text { Abs. of Test } \\
\text { Solution }\end{array}\end{array}$ & $12.5 \mu \mathrm{g} / \mathrm{ml}$ & $12.5 \mu \mathrm{g} / \mathrm{ml}$ & $12.5 \mu \mathrm{g} / \mathrm{ml}$ & $12.5 \mu \mathrm{g} / \mathrm{ml}$ & $12.5 \mu \mathrm{g} / \mathrm{ml}$ & $12.5 \mu \mathrm{g} / \mathrm{ml}$ \\
\hline $\begin{array}{c}\text { \%age of Label } \\
\text { Claim }\end{array}$ & 99.76 & 0.365 & 0.364 & 0.365 & 0.362 & 0.364 \\
\hline Average & 99.99 & 100.27 & 100.00 & 100.27 & 99.45 & 100.00 \\
\hline Standard Deviation & \pm 0.19 & \pm 0.09 & \pm 0.19 & $\begin{array}{c}\text { Standard } \\
\text { Deviation }\end{array}$ & \pm 0.19 & \pm 0.09 \\
\hline
\end{tabular}

\section{Specificity}

The specificity is defined as the ability to dis-unite the analyte in the presence of other components like matrix components. Specificity shows that the procedure is unaffected by the presence of excipients or impurities. Specificity is performed by running a standard solution (as identification test) comparing with a placebo run.

\section{Placebo Preparation}

Prepare placebo by taking excipients of preparation, without active ingredient (Amoxicillin trihydrate), mixed to made $200 \mathrm{~g}$ in following ratio.

Colloidal silicon dioxide (3.322 g), Sodium benzoage $(0.246 \mathrm{~g})$, Sodium citrate $(0.246 \mathrm{~g})$, Carboxy methyl cellulose sodium ( $0.984 \mathrm{~g})$, Bubble gum (dry essence) $(0.615 \mathrm{~g})$, Methylparaben (0.203 g), Propylparaben $(0.203 \mathrm{~g})$, Sucrose $(192.86 \mathrm{~g})$ and saccharin sodium $(0.123 \mathrm{~g})$.

\section{Limit of Detection (LOD)}

The least amount of an analyte could be determined, but it is not necessarily to evaluate it quantitatively in prescribed experimental situations is termed as LOD. It is important for the determination of little amount of drugs besides impurities and placebo. The LOD is usually cited as the concentration giving a signal to noise ratio of 2:1 which is confirmed near this value by examining a number of samples.

As per following equation, ${ }^{\circ}$ signal to noise ${ }^{\circ}$ ratio is determined:

$$
\mathrm{s}=\mathrm{H} / \mathrm{h}
$$

$\mathrm{H}$ correspond to peak's height relating to constituent

$h$ is absolute value of highest noise-fluctuation in the chromatogram initiation from the baseline of a blank (solution).

Remarks: There is no any impurity detected under the conc. $2.5 \mu \mathrm{g} / \mathrm{ml}$. The absorbance peak wavelength $(\Lambda)$ is same and no ${ }^{\circ}$ signal to noise ${ }^{\circ}$ ratio found.

\section{Limit of Quantification (LOQ)}

The determination of the least amount of an analyte in a sample with acceptable accuracy and precision is called LOQ. Lowest concentration of analyte (Amoxicillin trihydrate) was determined up-to $5 \mu \mathrm{g} / \mathrm{ml}$. The inter-/intra-day response on the Amoxicillin concentration was scanned (concentration and absorbance) and found significant results that was given in Figures 4A, 4B, 4C and 4D. 

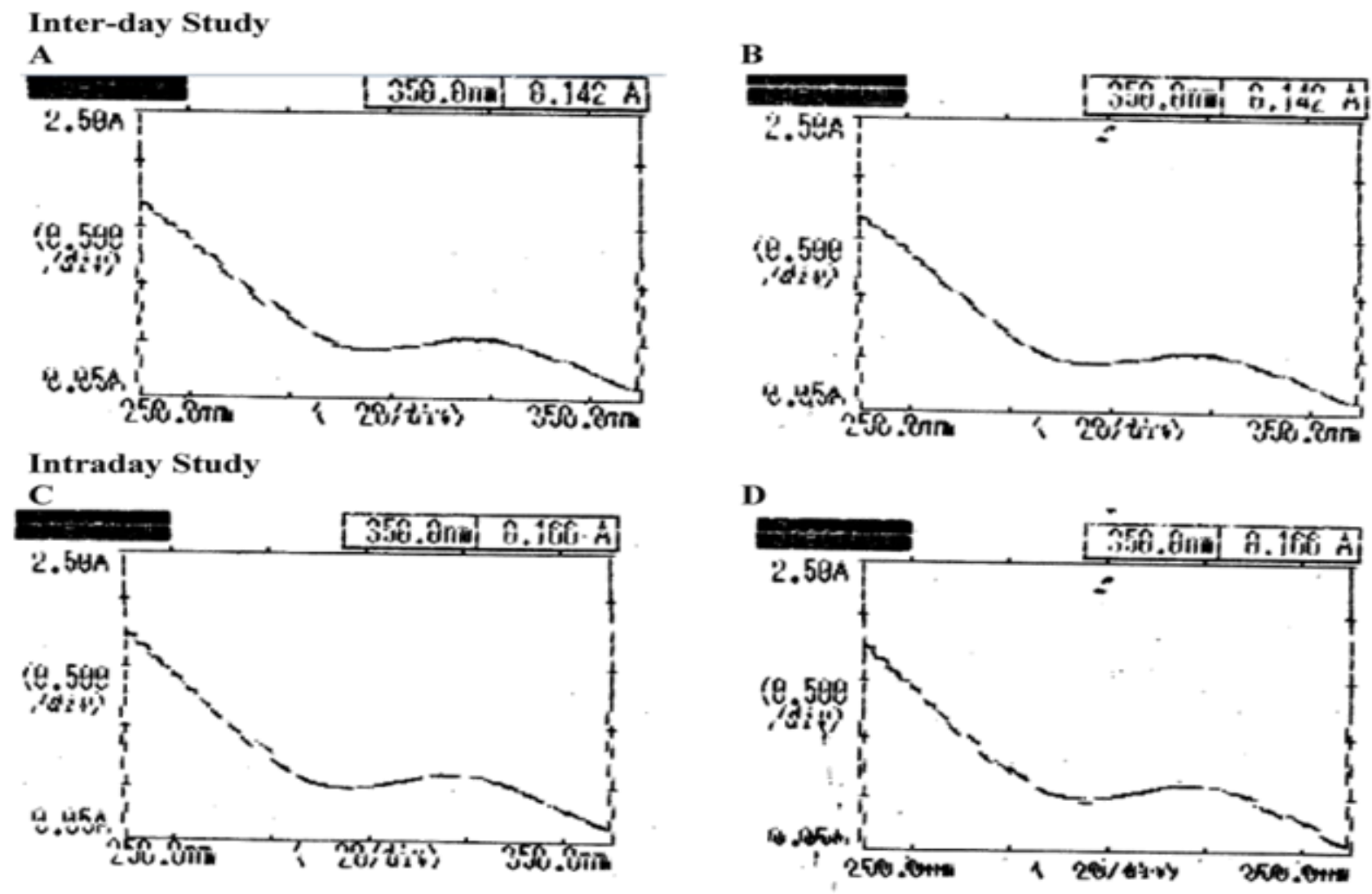

Figure 4. A: Scan of standard $(12.5 \mu \mathrm{g} / \mathrm{ml}$ Amoxicillin solution), B: Scan of test sample $(12.5 \mu \mathrm{g} / \mathrm{ml}$ Amoxicillin solution), C: Scan of standard (12.5 $\mu \mathrm{g} / \mathrm{ml}$ Amoxicillin solution), D: Scan of test sample $(12.5 \mu \mathrm{g} / \mathrm{ml}$ Amoxicillin solution).

\section{DISCUSSION}

The data presented the linear regression line between concentration and absorbance of analyte followed the Beer's Lambert law [21]. According to the Linear regression the $Y=0.002000=3.014 \mathrm{e}-008$ and correlation coefficient of $r=1.000$. This revealed that linear relationship between absorbance and concentration of Amoxicillin trihydrate has the significant configuration as given in Figure $\mathbf{2 H}$ and Table 4. The validation of repeatability and reproducibility were performed with 03 samples in 2 replicates having concentration of $12.5 \mu \mathrm{g} / \mathrm{ml}$ of Amoxicillin trihydrate. Each result showed the reliable and substantial variation when compared with theoretical results as given in Table 5 [22]. In addition accuracy, limit of detection (LOD), limit of quantification (LOQ) and robustness were also evaluated by employing the proposed spectrophotometric methods and found reliable values on comparison with standard outcomes [23, 24] presented in Tables 7 and 8.

\section{CONCLUSION}

Our study demonstrated the authentication the evaluation of Amoxicillin trihydrate in various pharmaceutical preparations and bulk that newly designed with UV/Visible spectroscopic method. The proposed spectrophotometric technique is quite simple, sensitive, reproducible, economical and fast when compared with other stated methods employed for the determination of Amoxicillin. In conclusion, this validation mode will be a worth for the monotonous examination of Amoxicillin trihydrate either in the bulk and solid pharmaceutical dosage form.

\section{REFERENCES}

1. Freitas SK, Silva VLd, Araújo AN, Montenegro MC, Reis BF, Paim APS. A multicommuted flow analysis method for the photometric determination 
of amoxicillin in pharmaceutical formulations using a diazo coupling reaction. J. Braz. Chem. Soc. 2011; 22(2):279-85.

2. Qader HA, Fakhre NA. Spectrophotometric determination of amoxicillin trihydrate in pure and pharmaceutical dosage forms. Ibn Al Haitham J. for Pure and Appl. Sci. 2017; 28(3):142-53.

3. Abdulameer SS, Al-Saidi KH. Simultaneous determination of amoxicillin and potassium clavulanate antibiotics in pharmacueutical sample using derivative spectrophotometric method. J. Biot. Res. C. 2011; 5(3):49-60.

4. Prakash K, Raju PN, Kumari KS, Narasu ML. Spectrophotometric estimation of amoxicillin trihydrate in bulk and pharmaceutical dosage form. E- J. Chem. 2008; 5:40-45.

5. Santos SM, Roch J, Mafra L. NMR crystallography: toward chemical shift-driven crystal structure determination of the $\beta$-Lactam antibiotic amoxicillin trihydrate. Cryst Growth Des. 2013; 13(6):2390-2395.

6. Chitlange SS, Tawargeri SR, Chaturvedi KK. Simultaneous Determination of Amoxicillin trihydrate and Ambroxol hydrochloride in solid dosage form by spectrophotometric and stability indicating RP-HPLC method. Asian J. Research Chem. 2011; 4(6):1025-30.

7. Al-Abachi MQ, Hadi H. A developed spectrophotometric determination of amoxicillin forms via charge-transfer reaction with metol. AlNahrain J. Sci. 2007; 10(2):1-6.

8. Gujral RS, Haque SM. Simultaneous determination of potassium clavulanate and amoxicillin trihydrate in bulk, pharmaceutical formulations and in human urine samples by UV spectrophotometry. IJBS. 2010; 6(4):335.

9. Nikam DS, Bonde CG, Surana S, Venkateshwarlu G, Dekate P. Development and validation of RPHPLC method for simultaneous estimation of amoxicillin trihydrate and flucloxacillin sodium in capsule dosage form. Int J Pharm Tech Res. 2009; 1(3):935-9.

10. Kowalczuk D, Galewska A. HPLC analysis of amoxicillin using AccQ-Fluor reagent for precolumn derivatization. Pol. J. Environ. Stud. 2012; 21(1):139-43.

11. Huong VT, Hoang VD. Simultaneous determination of amoxicillin and clavulanate in combined tablets by non-derivative and derivative UV spectrophotometric techniques. Int $\mathrm{J}$ PharmTech Res. 2009; 1:1173-81.

12. Fan J, Ho L, Hobson P, Brookes J. Evaluating the effectiveness of copper sulphate, chlorine, potassium permanganate, hydrogen peroxide and ozone on cyanobacterial cell integrity. Water Res. 2013; 47(14):5153-64.

13. Dhoka M, Gawande V, Joshi P. HPTLC determination of amoxicillin trihydrate and bromhexine hydrochloride in oral solid dosage forms. JPSR. 2010; 2(8):477.

14. Zhu, W, Yang J, Wang Z, Wang C, Liu y, Zhang L. Rapid determination of 88 veterinary drug residues in milk using automated TurborFlow online cleanup mode coupled to liquid chromatography-tandem mass spectrometry. Talanta. 2016; 148:401-411.

15. Mbinze JK, Mpasi JN, Maghe E, Kobo S, Mwanda R Mulumba G, Hubert P. Application of Total Error Strategy in Validation of Affordable and Accessible UV-Visible Spectrophotometric Methods for Quality Control of Poor Medicines. AJAC. 2015; 6(02):106-110.

16. Nikolov A, Nedyalkov N, Nikov R, Atanasov P, Alexandrov M. Characterization of $\mathrm{Ag}$ and $\mathrm{Au}$ nanoparticles created by nanosecond pulsed laser ablation in double distilled water. Appl. Surf. Sci. $2011 ; 257(12): 5278-5282$.

17. Safarnejad A, Shaghaghi M, Dehghan G, Soltani S. Binding of carvedilol to serum albumins investigated by multi-spectroscopic and molecular modeling methods. J Lumin. 2016; 176:149-158.

18. Beg S, Kohli K, Swain S, Hasnain MS. Development and validation of RP-HPLC method for quantitation of amoxicillin trihydrate in bulk and pharmaceutical formulations using Box-Behnken experimental design. J Liq Chromatogr R T. 2012; 35(3):393-406.

19. Ermer J, Ploss HJ. Validation in pharmaceutical analysis: Part II: central importance of precision to establish acceptance criteria and for verifying and improving the quality of analytical data. J Pharmaceut Biomed. 2005; 37(5):859-870.

20. Bryan CJ, Yeager DS, Brien JM. Replicator degrees of freedom allow publication of misleading failures to replicate. P Natl Acad Sci USA. 2019; 116(51):25535-25545.

21. Gobrecht A, Bendoula R, Roger JM, Bellon V. Combining linear polarization spectroscopy and the Representative Layer Theory to measure the Beer-Lambert law absorbance of highly scattering materias. Anal. Chim. Acta. 2015; 853:486-494.

22. Bartlett J, Frost C. Reliability, repeatability and reproducibility: analysis of measurement errors in continuous variables. Ultrasound in Obstetrics and Gynecology: ISUOG. 2008; 31(4):466-75.

23. Saadati N, Abdullah MP, Zakaria Z, Sany SBT, Rezayi M, Hassonizadeh $\mathrm{H}$. Limit of detection and 
The Validation and Development of Analytical Technique for the Fast and Economical Evaluation of Amoxicillin in Solid Dosage form Through UV/Visible Spectroscopy

limit of quantification development procedures for organochlorine pesticides analysis in water and sediment matrices. Chem. Cent. J. 2013; 7(1):63.
24. Zhang $H$, Yu Y, Jiao J, Xing EP, Ghaoui LE, Jordan MI. Theoretically principled trade-off between robustness and accuracy. arXiv preprint arXiv. 2019; 1901:8573-8580. 